\title{
Abnormalities of the mitral valve in congenitally corrected transposition (discordant atrioventricular and ventriculoarterial connections)
}

\author{
LEON M GERLIS, NEIL WILSON, DAVID F DICKINSON \\ From Killingbeck Hospital, Leeds
}

SUMMARY Abnormalities of the mitral valve were found in $16(55 \%)$ of 29 necropsy specimens of hearts with congenitally corrected transposition of the great arteries (discordant atrioventricular and ventriculoarterial connections). These abnormalities were most commonly of cusp number $(21 \%)$ and tension apparatus $(21 \%)$. Dysplasia of the valve was less common (10\%), and other abnormalities identified included common valve, stenosis, and cleft valve. Some of the cases showed more than one morphological abnormality. The median age at death in those cases with mitral valve abnormalities was significantly higher than those without. More females than males had valves affected (ratio 2:1). Malformations such as ventricular septal defect and tricuspid or pulmonary valve anomalies were represented in similar proportions in cases with and without mitral anomalies.

Abnormalities of the tricuspid valve (the valve of the morphologically right ventricle), ${ }^{12}$ the pulmonary valve, and the subpulmonary area ${ }^{3-5}$ are well documented in hearts with congenitally corrected transposition. Less frequently the aortic valve may be abnormal $^{36}$ but as far as we are aware there has been no systematic study of or reference to abnormalities of the mitral valve in this condition. This paper documents the prevalence and nature of these abnormalities in 29 necropsy cases.

Throughout this paper the term mitral valve is used to designate the atrioventricular valve of the morphologically left ventricle.

\section{Patients and methods}

Thirty five heart specimens with congenitally corrected transposition from the pathological collection at Killingbeck Hospital were examined for evidence of abnormality of the mitral valve. After initial inspection six hearts were discarded because of extensive tissue damage from previous dissection at

Requests for reprints to Dr L M Gerlis, Killingbeck Hospital, York Road, Leeds LS14 6UQ.

Accepted for publication 13 January 1986 operation or necropsy that precluded accurate evaluation. A detailed macroscopic examination of the atrioventricular and arterial valves was made in the remaining 29 cases. Abnormalities of the mitral valve were listed and grouped according to their major morphological characteristics.

\section{Results}

There were 15 female and 10 male patients who were aged from 1 day to 24 years at the time of death (median 19 months). Patients with normal mitral valves (age range 1 day to 11 years, mean 1.9 years) were significantly younger at death than those in whom the mitral valve was abnormal (age range 1 day to 24 years, mean 6.5 years, SEM 2.0 years).

\section{MITRAL ABNORMALITIES}

Abnormalities of the mitral valve were found in $\mathbf{1 6}$ $(55 \%)$ of the 29 specimens. The Table summarises the details.

\section{Valves with multiple cusps}

A valve with more than two cusps was regarded as abnormal. In this series, one valve had three cusps, three were quadricuspid, and two had five cusps (Fig. 1). In each case the cusps were separated by 
Table Morphological features of cases with an abnormal mitral valve

\begin{tabular}{|c|c|c|c|c|c|c|c|}
\hline $\begin{array}{l}\text { Case } \\
\text { No }\end{array}$ & Age & Sex & Mitral abnormality & $V S D$ & Tricuspid abnormality & Pulmonary outlet & $\begin{array}{l}\text { Other } \\
\text { abnormalities }\end{array}$ \\
\hline $\begin{array}{l}1 \\
2 \\
3\end{array}$ & $\begin{array}{l}22 \mathrm{mo} \\
24 \mathrm{yr} \\
?\end{array}$ & $\begin{array}{l}\mathbf{M} \\
\mathbf{F} \\
\mathbf{M}\end{array}$ & $\begin{array}{l}\text { Multicuspid (4) } \\
\text { Tension apparatus } \\
\text { Multicuspid (3), tension } \\
\text { apparatus, common } \\
\text { valve }\end{array}$ & $\begin{array}{l}\text { Large } \\
\text { Small } \\
\text { Large }\end{array}$ & $\begin{array}{l}\text { Normal } \\
\text { Multicuspid (5) } \\
\text { Tension apparatus, } \\
\text { common valve }\end{array}$ & $\begin{array}{l}\text { Atresia } \\
\text { Moderate stenosis } \\
\text { Normal }\end{array}$ & $\begin{array}{l}\text { Right aortic arch } \\
\text { TAPVC, single } \\
\text { coronary } \\
\text { ostium, AVSD }\end{array}$ \\
\hline 4 & 10 wk & $\mathbf{M}$ & $\begin{array}{l}\text { Pronounced scalloping, } \\
\text { tension apparatus }\end{array}$ & Large & Atresia & Normal & \\
\hline $\begin{array}{l}5 \\
6 \\
7 \\
8 \\
9\end{array}$ & $\begin{array}{l}10 \mathrm{mo} \\
8 \mathrm{yr} \\
16 \mathrm{yr} \\
5 \mathrm{mo} \\
13 \mathrm{yr}\end{array}$ & $\begin{array}{l}\mathbf{M} \\
? \\
\mathbf{M} \\
\mathbf{F} \\
\mathbf{F}\end{array}$ & $\begin{array}{l}\text { Dysplasia } \\
\text { Multicuspid (4) } \\
\text { Tension apparatus } \\
\text { Tension apparatus, cleft } \\
\text { Dysplasia }\end{array}$ & $\begin{array}{l}\text { None } \\
\text { Small } \\
\text { Moderate } \\
\text { Large } \\
\text { Small }\end{array}$ & $\begin{array}{l}\text { Ebstein's } \\
\text { Stenosis } \\
\text { Dysplasia } \\
\text { Tension apparatus } \\
\text { Normal }\end{array}$ & $\begin{array}{l}\text { Mild stenosis } \\
\text { Moderate stenosis } \\
\text { Normal } \\
\text { Atresia } \\
\text { Atresia }\end{array}$ & $\begin{array}{l}\text { Right aortic arch } \\
\text { Right aortic arch, } \\
\text { bilatergl SCY }\end{array}$ \\
\hline $\begin{array}{l}10 \\
11 \\
12 \\
13\end{array}$ & $\begin{array}{l}14 \text { yr } \\
? \\
8 \text { yr } \\
1 \text { day }\end{array}$ & $\begin{array}{l}\mathbf{F} \\
\mathbf{F} \\
\mathbf{M} \\
\mathbf{F}\end{array}$ & $\begin{array}{l}\text { Multicuspid (4) } \\
\text { Stenosis } \\
\text { Multicuspid (5) } \\
\text { Pronounced scalloping, } \\
\text { tension apparatus }\end{array}$ & $\begin{array}{l}\text { Small } \\
\text { Moderate } \\
\text { None } \\
\text { None }\end{array}$ & $\begin{array}{l}\text { Dysplasia } \\
\text { Ebstein's } \\
\text { Ebstein's } \\
\text { Ebstein's }\end{array}$ & $\begin{array}{l}\text { Moderate stenosis } \\
\text { Atresia } \\
\text { Normal } \\
\text { Mild stenosis }\end{array}$ & 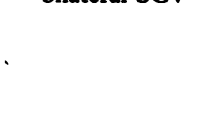 \\
\hline 14 & $19 \mathrm{mo}$ & $\mathbf{F}$ & $\begin{array}{l}\text { Dysplasia, common } \\
\text { valve }\end{array}$ & Large & $\begin{array}{l}\text { Dysplasia, common } \\
\text { valve }\end{array}$ & Atresia & TAPVC, AVSD \\
\hline $\begin{array}{l}15 \\
16\end{array}$ & $\begin{array}{l}16 \mathrm{mo} \\
11 \mathrm{mo}\end{array}$ & $\begin{array}{l}\mathbf{F} \\
\mathbf{F}\end{array}$ & $\begin{array}{l}\text { Multicuspid (5) } \\
\text { Pronounced scalloping }\end{array}$ & $\begin{array}{l}\text { Small } \\
\text { Small }\end{array}$ & $\begin{array}{l}\text { Ebstein's } \\
\text { Ebstein's }\end{array}$ & $\begin{array}{l}\text { Normal } \\
\text { Moderate stenosis }\end{array}$ & \\
\hline
\end{tabular}

^Pulmonary outflow tract tag or membranous septal aneurysm.

VSD, ventricular septal defect; AVSD, atrioventricular septal defect; SCV, superior caval vein; TAPVC, total anomalous pulmonary venous connection.

Figure in parentheses after multicuspid valve is number of cusps.

commissural areas defined by the presence of commissural chordae. ${ }^{7}$ In a further three cases the posterior cusp was divided into two or more well separated sections. Shortening and dysplasia of the chordae in these cases, however, made it impossible to recognise commissural chordae. These divisions were far in excess of the scalloping of the mitral leaflets described in normal hearts. ${ }^{89}$ None of the leaflets were dysplastic and, as far as it was possible to judge in fixed specimens, these abnormalities probably would not have created any haemodynamic disturbance. The valves with three cusps also had abnormalities of the tension apparatus. In nearly all of the cases in which the mitral valve had more than two cusps, the tricuspid and pulmonary valves were also abnormal; for example Ebstein's anomaly of the tricuspid valve was present in both cases in which the mitral valve had five cusps.

\section{Abnormalities of tension apparatus}

Six cases $(21 \%)$ had abnormalities of the tension apparatus that comprised multiple or compound papillary muscles and anomalous chordal attachment. In three cases there were multiple papillary muscles. In one this affected both anterior and posterior papillary groups, with ten papillary muscles supporting three cusps (Fig 2), while in the other two only the posterior papillary muscles were increased.

There were two cases with short dysplastic chordae. In one of these the anterior cusp of the mitral portion of a common valve was almost sessile while the posterolateral cusp had numerous papillary mus- cles and is included in the group mentioned above (Fig 3). The other case showed numerous short dysplastic chordae attached to a bizarre posterior papillary muscle (Fig. 4). Two cases showed parachute like malformations of the papillary muscle in that most of the chordae were attached to a single papillary muscle group. In one of these cases small tenuous chordae were attached to a delicate posterior papillary muscle. In the other, one cusp of a cleft valve had a single thick chordal attachment to one portion of a duplex papillary muscle while the remaining chordae were attached to the other portion (Fig 4).

\section{Dysplasia, stenosis, common valve, or cleft}

There were three cases $(10 \%)$ of valve dysplasia. Two had a rather redundant rolled edge appearance to the cusps (Fig 5) that might have resulted in incompetence of the valve. In the remaining case the dysplasia was more nodular and the valve was hypoplastic with a supravalvar ridge and appeared to be considerably stenosed (Fig. 5). Of the two cases of common atrioventricular valve one had abnormalities of tension apparatus and one case also had dysplastic leaflets. The cleft valve may also have been incompetent, but though the cleft is impressive in the fixed specimen (Fig. 4) it is impossible to be certain about the presence of regurgitation during life.

ADDITIONAL ABNORMALITIES

In all cases the aortic valve was normal. 


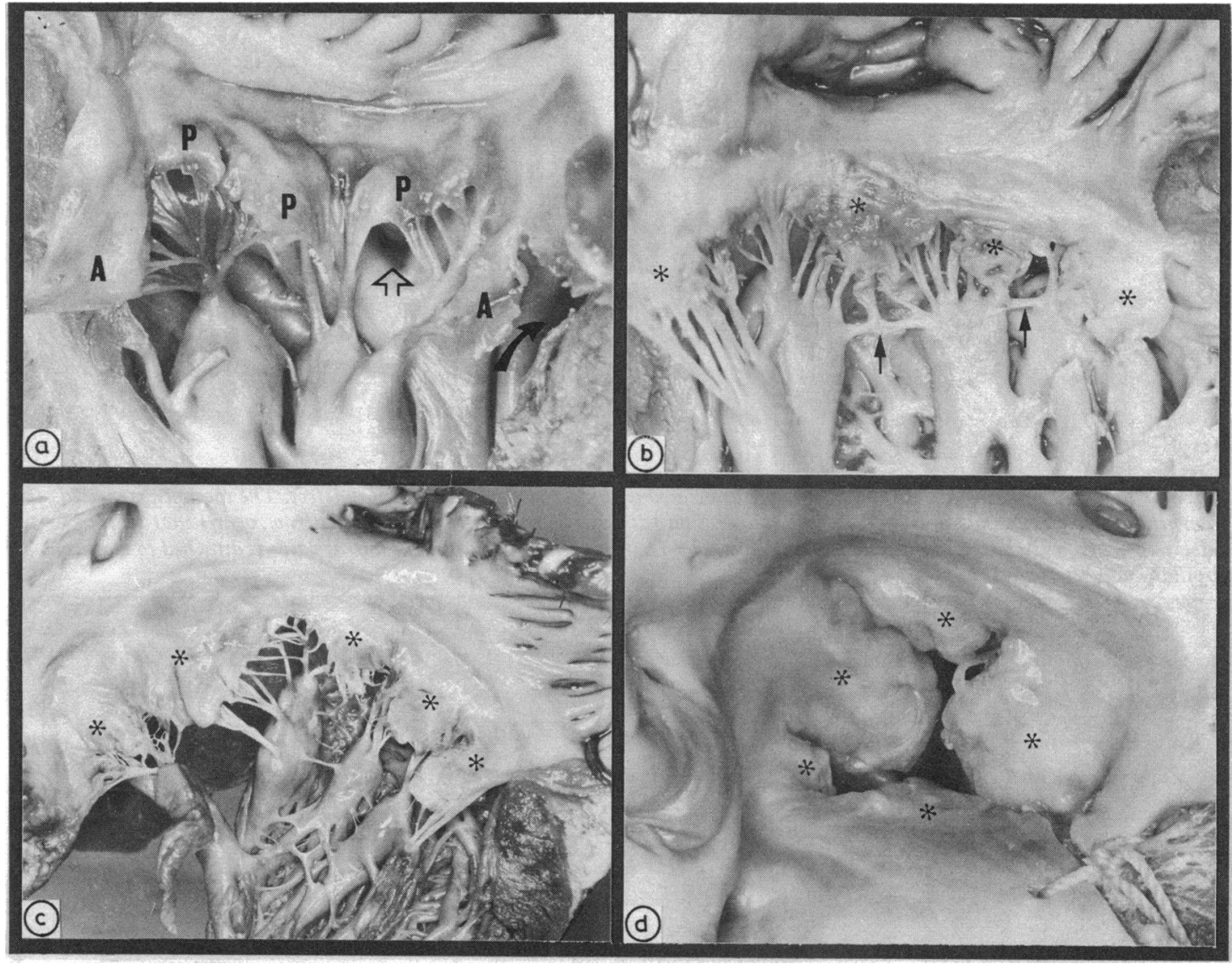

Fig. 1 Valves with more than two cusps. (a) There are four cusps. The anterior cusp ( $A$ ) has been divided. Three posterior cusps $(P)$ are present. Closed arrow, ventricular septal defect; open arrow, pulmonary outlet (case 1). (b) Pronounced scalloping of the posterior leaflet of the mitral valve giving the appearance of four equal well formed cusps (asterisked). There is some shortening of chordae and bridging between the papillary muscles (arrowed) (case 4). (c) A valve with five cusps attached to confluent papillary muscles (case 12). (d) Atrial view of a five cusp valve in the closed position (case 15).

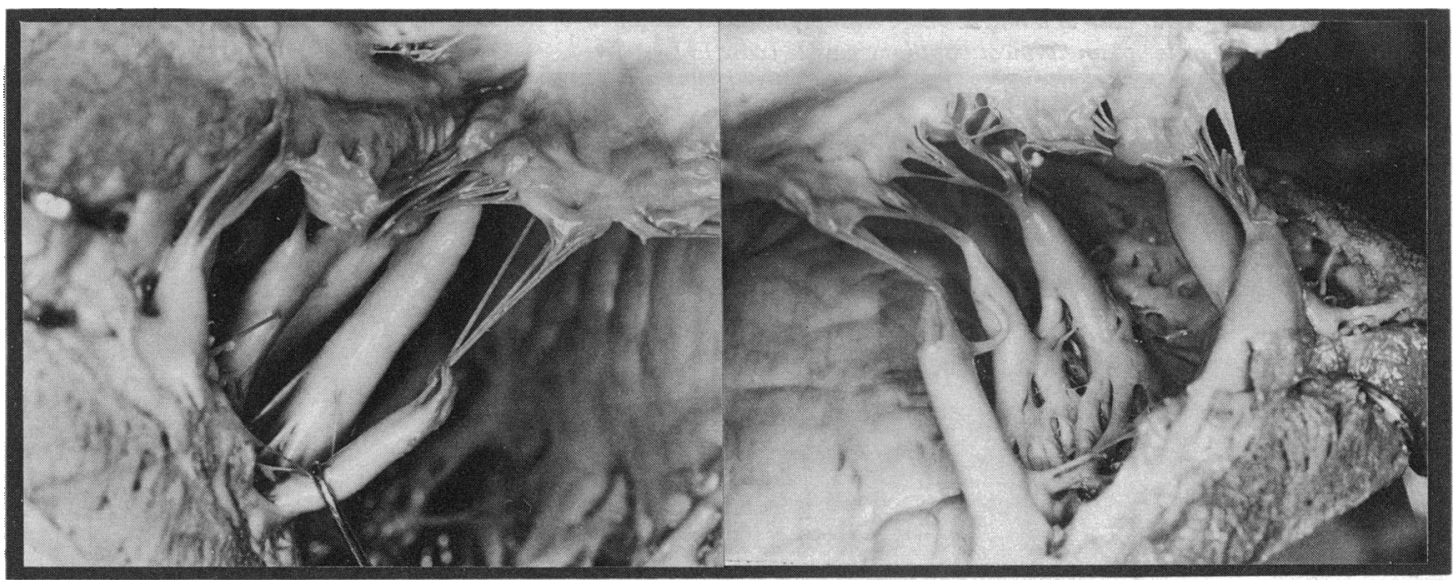

Fig. 2 A montage view of an opened mitral valve showing ten papillary muscles in two groups of five (case 7). 


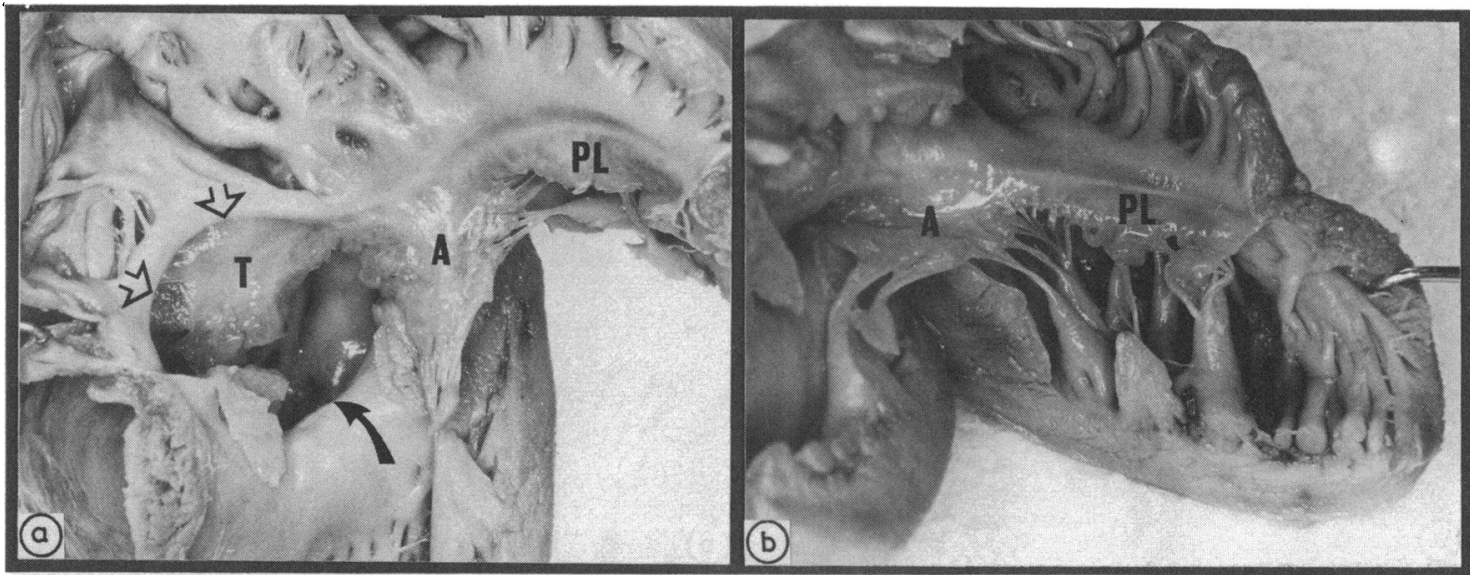

Fig. 3 (a) The straddling atrioventricular valve associated with ar: atrioventricular septal defect. The specimen is viewed from behind. A, anterior mitral cusp; PL, posterolateral mitral cusp; $T$, tricuspid valve; closed arrow, ventricular septal defect; open arrows, margins of ostium primum defect. (b) The posterolateral cusp of the mitral valve is attached to numerous papillary muscles (case 3 ).

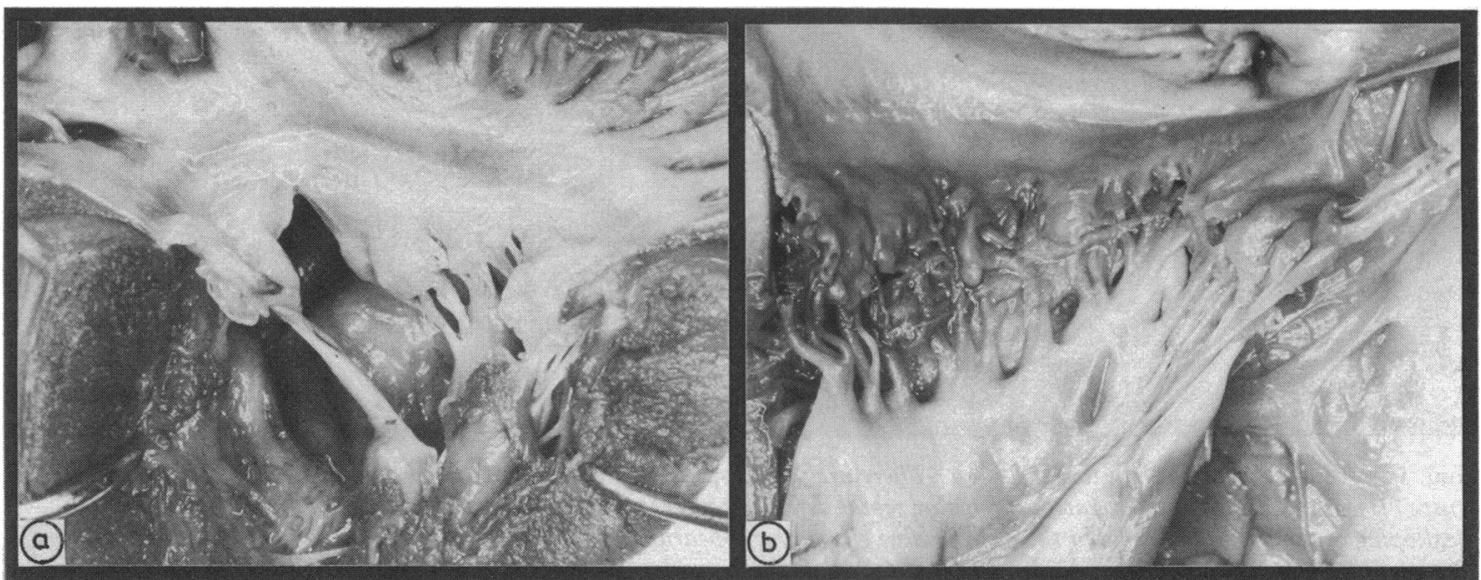

Fig. 4 (a) A deeply cleft mitral valve with an abnormally thick solitary chorda attached to a bifid papillary muscle (case 8). (b) The posterior cusp of a mitral valve with pronounced scalloping of the posterior cusp showing the attachment of multiple shortened chordae to an atvicical Dasillarv muscle (case 13).

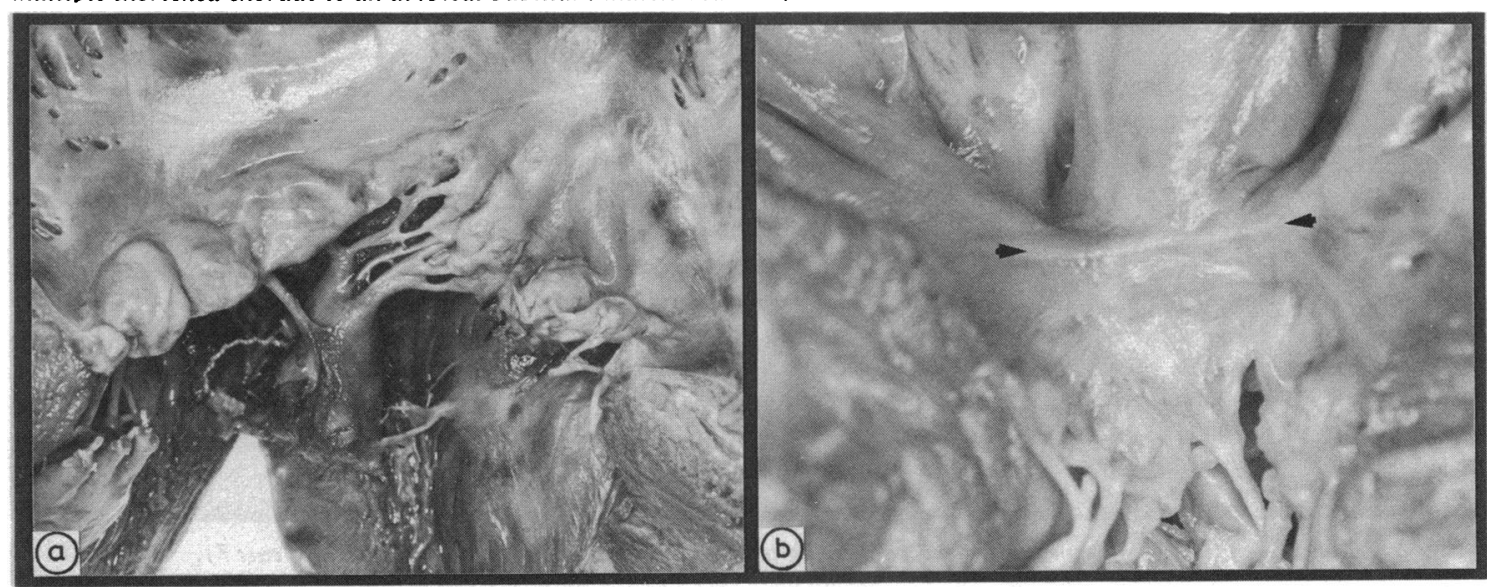

Fig. 5 (a) The dysplastic thickened cusps of this mitral valve show some doming similar to that of floppy or mucinous degeneration. The chordae are also thickened (case 9). (b) A hypoplastic dysplastic and stenosed mitral valve with a transverse supravalvar ridge (arrowed) (case 11). 


\section{Tricuspid lesions}

Abnormalities of the tricuspid valve were present in 25 cases $(86 \%)$. Although tricuspid valve abnormalities were represented in similar proportions in the groups with and without mitral anomalies, there were six cases of Ebstein's anomaly in the group with mitral valve anomalies against two cases in those with normal mitral valves.

\section{Ventricular septal defects}

Ventricular septal defects were present in 23 cases $(79 \%)$ and were represented in similar proportions in the groups with and without mitral valve anomalies.

\section{Pulmonary valve and subpulmonary region}

Pulmonary atresia $(10 / 29)$ or stenosis $(9 / 29)$ were common and in addition there were five cases with subpulmonary tags or aneurysms of the membranous septum that may have caused obstruction to blood flow. Outlet abnormalities of the morphologically left ventricle were represented in similar proportions in those cases with and without mitral valve anomalies.

\section{Other minor abnormalities}

There were five cases with a right sided aortic arch, two cases with bilateral superior caval veins, and two cases of total anomalous pulmonary venous connection. There was one case each of single coronary ostium, left juxtaposition of the atrial appendages, and right ventricular diverticulum.

\section{Discussion}

It is clear that in congenitally corrected transposition of the great arteries abnormalities of the mitral valve are common. Although two earlier papers refer to mitral insufficiency in this condition, ${ }^{10}{ }^{11}$ it is clear that these workers were referring to the valve of the morphologically right ventricle. It is surprising that there has been no mention of abnormalities of the mitral valve in previous detailed morphological and clinical studies of this condition. ${ }^{12}$ This may be explained by the fact that the abnormalities we found, though numerous, were relatively minor and for the most part are unlikely to have produced serious haemodynamic disturbance. Attention has naturally focused on those defects which are surgically more important.

In any study of fixed specimens it is often difficult to be certain of the severity of the haemodynamic disturbance likely to result from a given anatomical lesion and in this study we felt that only in the case with stenosis of the valve would the disturbance have been important. In a further three cases, two with cusp dysplasia and one with a cleft, regur- gitation might have been present during life. It is therefore unlikely that abnormalities of the mitral valve will be of surgical importance in this group of patients. Nevertheless, since our series is a small and selected group it is possible that occasionally the mitral lesion may be more important.

Although the cases with abnormal mitral valves were significantly older at the time of death than those with normal mitral valves it is clear from the nature of the mitral lesions (with the possible exception of the three cases with cusp dysplasia) that they were not acquired in postnatal life.

\section{Conclusion}

The mitral valve anomalies we have described are minor. Whether in the long term they will become clinically important in the survivors of surgical treatment or in those rare examples of corrected transposition without additional abnormalities remains to be seen.

LMG is supported by the National Heart Research Fund.

\section{References}

1 Allwork SP, Bentall HH, Becker AE, et al. Congenitally corrected transposition of the great arteries: morphologic study of 32 cases. Am $\mathcal{F}$ Cardiol 1976; 38: 910-23.

2 Bjarke BB, Kidd BSL. Congenitally corrected transposition of the great arteries, a clinical study of 101 cases. Acta Paediatr Scand 1976; 65: 153-60.

3 Goldstein RE, Beller BM, Maeir D. Corrected transposition of the great vessels associated with bicuspid semilunar valves. Am $\mathcal{F}$ Med 1968; 45: 954-8.

4 Anderson RH, Becker AE, Gerlis LM. The pulmonary outflow tract in classically corrected transposition. $f$ Thorac Cardiovasc Surg 1975; 69: 747-57.

5 Levy MJ, Lillehei CW, Elliot LP, Carey LS, Adams P, Edwards JE. Accessory valvular tissue causing subpulmonary stenosis in corrected transposition of great vessels. Circulation 1963; 27: 494-502.

6 Deanfield JE, Anderson RH, Macartney FJ. Aortic atresia with "corrected transposition of the great arteries" (atrioventricular and ventriculoarterial discordance). Br Heart $\mathcal{F}$ 1981; 46: 683-6.

7 Lam JHC, Ranganathan N, Wigle ED, Silver MD. Morphology of the human mitral valve. 1. Chordae tendineae: a new classification. Circulation 1970; 41: 449-58.

8 Davies MJ. Pathology of cardiac valves. Post graduate pathology series. London: Butterworths, 1980: 63-5.

9 Anderson RH, Becker AE. Cardiac anatomy. London: Gower, Churchill Livingstone, 1980: 4.4-6.

10 Malers E, Bjork VO, Cullhed I, Lodin H. Transposition functionally totally corrected, associated with "mitral" insufficiency. Am Heart f 1960; 59: 816-34.

11 Talner NS, Stern AM, Sloan HE. Congenital mitral insufficiency. Circulation 1961; 23: 339-49. 